\title{
Determination of Acetylsalicylic acid and Naproxen in waste and Tap Water of the Municipal Area of the Sukkur City by SPE-LC-MS/MS
}

\author{
Waheed Ali Mirbahar ${ }^{1}$, Mir Munsif Ali Talpur ${ }^{* 1}$, Tajnees Pirzada ${ }^{1}$ and \\ Syed Ghulam Musharraf ${ }^{2}$ \\ ${ }^{*}$ Institute of Chemistry, Shah Abdul Latif University, Khairpur, Sindh, Pakistan. \\ ${ }^{2}$ International Center for Chemical and Biological Sciences (ICCBS), University of Karachi, \\ Karachi-75270, Pakistan. \\ *Corresponding Author Email: mirmunsif_salu@yahoo.com \\ Received 24 February 2020, Revised 10 August 2020, Accepted 15 September 2020
}

\begin{abstract}
This study is based on an environmental assessment of acetylsalicylic acid and naproxen in waste and tap water samples of twenty different locations of municipal area of Sukkur city, Sindh, Pakistan. Both drugs belong to the most frequently used Non-Steroidal Anti-Inflammatory Drugs (NSAIDs) group. The specified pharmaceuticals were extracted from the wastewater and tap water samples by Solid Phase Extraction (SPE) method using Waters Oasis hydrophilic lipophilic balance (HLB) cartridges. Liquid Chromatography-Tandem Mass Spectrometry (LC-MS/MS) technique was applied for the detection and quantification of selected drugs. Negative Electron Spray Ionization (ESI) was used along with Multi Reaction Monitoring (MRM) mode. Pharmaceuticals concentration were found 7.38-827 $\mu \mathrm{g} / \mathrm{L}$ and 5.47-328.95 $\mu \mathrm{g} / \mathrm{L}$ in waste and tap water samples, respectively. The results obtained are comparable with the data reported in literature. Human health risk assessment caused by acetylsalicylic acid and naproxen in aquatic media was observed by applying Risk Quotient (RQ) approach. The calculated RQ values are low enough (order of $10^{-3}$ to $10^{-5}$ ) to cause a direct risk for consumers, but their presence in water may pose a danger synergistically.
\end{abstract}

Keywords: Waste water, Tap water, Non-steroidal anti-inflammatory drugs (NSAIDs), Solid phase extraction (SPE), Liquid chromatography-mass spectroscopy (LC-MS/MS), Risk assessment.

\section{Introduction}

Water is the vital natural source for health and survival of living things [1]. The availability of pure drinking water for human beings on earth is a great challenge due to industrialization, urbanization and ever increasing population in present time [2]. All unnecessary materials entering into water through various unhealthy activities by mankind causes water pollution [3]. Being a universal solvent, it is directly related to basic need for living creatures, but also a major source to cause diseases. According to World Health Organization (WHO), 80\% diseases are waterborne. Globally $3.1 \%$ population dies due to the inappropriate quality of water [4]. Major sources of water pollution are: industrial waste full of heavy metals, domestic waste, marine dumping, radioactive waste and atmospheric deposition [5]. Immune suppression, reproductive failure, skin diseases, cholera, vomiting, typhoid, extensively drug resistant (XDR) fever, 
including damage of flora and fauna are some horrible episodes of polluted water [6].

Water pollution by pharmaceutically active compounds (PhACs) is one of the modern world health challenging problem which constitute a health risk to humans, animals as well as aquatic ecosystems [7].

Worldwide thousands of tons of pharmaceuticals are manufactured annually, which enter into aquatic media [8]. Hence continuous monitoring of the aquatic environment is essential for the quality status of water because water contamination affects the endocrine system of humans, negative effects on fish, bacteria, algae, plants and a particular risk for pregnant women, their babies as well as children along with aquatic organisms.. Humans and animal health care along with crop production is maintained by bulk use of pharmaceuticals which may enter the environment by hospital effluents, sewage sludge, municipal sewage, landfill leachates, contaminated liquid manure, septic tanks and livestock activities etc. [9]. Many purification techniques are being applied to get pure drinking water like chlorination, ozonation, bank filtration and slow sand filtration etc. But they are not much effective for purification of organic pollutants, especially pharmaceuticals due to their complex and non-biodegradable nature [10]. Work on pollutants have been mostly focused on low concentration contaminants like pharmaceuticals and their metabolites due to the high transformation rate in the environment and ineffective removal processes [11] which causes their presence in drinking water [12]. These drugs taken by humans and animals due to incomplete metabolism are excreted as parental compounds, synthetic precursors or their metabolites through urine and feces or manufacturing [13].
Non-steroidal anti-inflammatory drugs (NSAIDs) are most commonly prescribed or self-medicated, as pain killers and fever reducing drugs in humans as well as at the veterinary side [14]. NSAIDs constitute human health issues like myocardial infarction, gastrointestinal bleeding, renal failure and reproduction system of aquatic organisms [15]. NSAIDs cause different types of ulcers and their chronic use may produce intestinal perforations [16]. Metabolites are by-product derivatives of parent pharmaceutical compounds formed biotically or abiotically [17]. Drug metabolism in the human body involves the conversion of parent pharmaceuticals into more soluble \& more polar metabolites through a series of complex reactions for the purpose of physiological action and easy elimination [18]. Drug metabolites, also have ability to revert into their original form of the drug. These bio transformation products undergo further reactions to produce more reactive metabolites. These bio-active metabolites are dangerous to humans, as they can bind to proteins and other cellular parts, to disrupt cellular function, a toxic effect and an immune response or none at all. This may also inhibit the activity of cytochrome enzymes, affecting the metabolism of other drugs; consequently they accumulate inside the body to cause severe toxic effects [19]. Regular intake of drugs for long time, even at sub-therapeutic level cause acute and chronic effects on human health [20].

\section{Materials and Methods Chemicals Required}

Ultra-pure standards of acetylsalicylic acid and naproxen were purchased from Sigma-Aldrich (Germany). Organic solvents (methanol, acetone and ethyl acetate) of analytical grade (Merck, Germany) were used to prepare stock solutions and stored at $-18^{\circ} \mathrm{C}$. 
LC-MS/MS grade formic acid (Thermo Fisher Scientific. Waltham, MA, USA).

\section{Sampling}

The tap and waste water samples were collected directly in 3L pre washed polyethylene plastic bottles from twenty different locations of municipal area of Sukkur city, Sindh, Pakistan, they were immediately transferred to the laboratory in a portable icebox and extracted within $48 \mathrm{~h}$ to avoid further degradation. For wastewater, scoop-type device was used and then the samples passed through a $2 \mathrm{~mm}$ sieve to remove sludge before entering into a collection unit. All glass wares were thoroughly cleaned, oven dried at $300^{\circ} \mathrm{C}$ for decontamination about $8 \mathrm{~h}$ and finally rinsed with Millipore Quality (Milli-Q) water before use. Milli-Q water purification system (Millipore Corporation, Bedford, MA, USA). Samples were collected randomly following the guidelines of Environmental Protection Agency (EPA) [21] from the locations shown in Table 1 Global Positioning System (GPS) was adopted to locate the position of a place properly at latitudes and longitudes.

\section{Solid Phase Extraction (SPE) of Raw Water Samples}

Each water sample was filtered through Whatman's filter paper (pore size 1.6 $\mu \mathrm{m})$. The filtrate was acidified with $3.5 \mathrm{M}$ $\mathrm{HCl}$ to $\mathrm{pH} 2$, in order to obtain maximum extraction of acidic compounds and stored at $4^{\circ} \mathrm{C}$. Solid phase extraction oasis HLB cartridges (waters, international, USA) were conditioned successively with $3 \mathrm{~mL}$ ethyl acetate-acetone $(50: 50 \mathrm{v} / \mathrm{v})$ mixture, $3 \mathrm{~mL}$ methanol and $3 \mathrm{~mL}$ ultrapure water (acidified to $\mathrm{pH} 2$ ). These solutions have good interaction with the selected drugs so they are used to enhance the extraction efficiency [22, 23].
Table 1. List of sampling stations of waste and tap water of municipal area of Sukkur city.

\begin{tabular}{|c|c|c|c|}
\hline \multirow[t]{2}{*}{$\begin{array}{l}\text { Sample } \\
\text { Nos. }\end{array}$} & \multirow[t]{2}{*}{$\begin{array}{c}\text { Sampling } \\
\text { Area }\end{array}$} & \multicolumn{2}{|c|}{$\begin{array}{c}\text { Sampling Stations, GPS } \\
\text { coordinates }\end{array}$} \\
\hline & & Latitude & Longitude \\
\hline 1 & Al-Madina colony & $27^{\circ} 42^{\prime} 59.0^{\prime \prime} \mathrm{N}$ & $68^{\circ} 50^{\prime} 50.6^{\prime \prime E}$ \\
\hline 2 & $\begin{array}{l}\text { Akhuwat Nagar } \\
\text { colony }\end{array}$ & $27^{\circ} 42^{\prime} 38.0^{\prime \prime} \mathrm{N}$ & $68^{\circ} 50^{\prime} 13.1^{\prime \prime} \mathrm{E}$ \\
\hline 3 & Bhosa line & $27^{\circ} 42^{\prime} \quad 15.9^{\prime \prime} \mathrm{N}$ & $68^{\circ} 51^{\prime} 54.9^{\prime \prime} \mathrm{E}$ \\
\hline 4 & Barrage colony & $27^{\circ} 41^{\prime} 28.1^{\prime \prime} \mathrm{N}$ & $68^{\circ} 51^{\boldsymbol{\prime}} 04.1^{\prime \prime} \mathrm{E}$ \\
\hline 5 & Bandar road & $27^{\circ} 41^{\prime} 27.8^{\prime \prime} \mathrm{N}$ & $68^{\circ} 52^{\prime} 05.5^{\prime \prime} \mathrm{E}$ \\
\hline 6 & Shikarpur phatak & $27^{\circ} 42^{\epsilon} 26.0^{\prime \prime} \mathrm{N}$ & $68^{\circ} 50^{\prime} 49.6^{\prime \prime} \mathrm{E}$ \\
\hline 7 & Shams abad & $27^{\circ} 41^{\prime \prime} 33.6^{\prime \prime N}$ & $68^{\circ} 51^{\prime} 22.8^{\prime \prime} \mathrm{E}$ \\
\hline 8 & Bhutta road & $27^{\circ} 41^{\prime \prime} 34.0^{\prime \prime} \mathrm{N}$ & $68^{\circ} 51^{\prime} 28.2^{\prime \prime} \mathrm{E}$ \\
\hline 9 & Canal road & $27^{\circ} 43^{\prime} 13.7^{\prime \prime N}$ & $68^{\circ} 48^{\prime} 35.1^{\prime \prime} \mathrm{E}$ \\
\hline 10 & Goldsmith bazaar & $27^{\circ} 41^{\prime} 38.1^{\prime \prime} \mathrm{N}$ & $68^{\circ} 52^{\prime} 03.7^{\prime \prime} \mathrm{E}$ \\
\hline 11 & Golimar & $27^{\circ} 42^{f} 27.4^{\prime \prime} \mathrm{N}$ & $68^{\circ} 50^{\prime} 58.1^{\prime \prime} \mathrm{E}$ \\
\hline 12 & Gharibabad & $27^{\circ} 41^{\prime \prime} 43.1^{\prime \prime N}$ & $68^{\circ} 51^{\prime} 43.0^{\prime \prime} \mathrm{E}$ \\
\hline 13 & Ghantaghar & $27^{\circ} 41^{\prime \prime} 40.2^{\prime \prime} \mathrm{N}$ & $68^{\circ} 51^{\prime} 51.0^{\prime \prime} \mathrm{E}$ \\
\hline 14 & High court road & $27^{\circ} 41^{\prime} 39.6^{\prime \prime} \mathrm{N}$ & $68^{\circ} 51^{\prime} 01.9^{\prime \prime} \mathrm{E}$ \\
\hline 15 & Hussaini road & $27^{\circ} 42^{\prime} 23.4^{\prime \prime} \mathrm{N}$ & $68^{\circ} 52^{t} 55.1^{\prime \prime} \mathrm{E}$ \\
\hline 16 & Local board & $27^{\circ} 41^{\prime} 51.2^{\prime \prime} \mathrm{N}$ & $68^{\circ} 52^{\prime} 25.4^{\prime \prime} \mathrm{E}$ \\
\hline 17 & Locus park & $27^{\circ} 41^{\prime \prime} 42.9^{\prime \prime} \mathrm{N}$ & $68^{\circ} 51^{\prime} 17.2^{\prime \prime} \mathrm{E}$ \\
\hline 18 & Makrani muhalla & $27^{\circ} 41^{\prime \prime} 20.8^{\prime \prime N}$ & $68^{\circ} 51^{\prime} 42.0^{\prime \prime} \mathrm{E}$ \\
\hline 19 & Miani road & $27^{\circ} 41^{\prime \prime} 23.6^{\prime \prime} \mathrm{N}$ & $68^{\circ} 51^{\prime} 43.5^{\prime \prime} \mathrm{E}$ \\
\hline 20 & Mobile market & $27^{\circ} 41^{\prime} 41.1^{\prime \prime} \mathrm{N}$ & $68^{\circ} 51^{\prime} 49.4^{\prime \prime} \mathrm{E}$ \\
\hline
\end{tabular}

Preconditioned, wet cartridges were loaded with $250 \mathrm{~mL}$ of wastewater and 1000 $\mathrm{mL}$ of tap water samples under vacuum at a flow rate of 12 to $15 \mathrm{~mL} / \mathrm{min}$, then washed with methanol-water (40:60 v/v) and dried under vacuum for $1 \mathrm{~h}$. Then adsorbed analytes were eluted by $10 \mathrm{~mL}(50: 50 \mathrm{v} / \mathrm{v})$ ethyl acetate-acetone mixture.

The eluates were concentrated by rotary vaporizer and subsequently transferred to $1.5 \mathrm{~mL}$ glass vials. Ultimately the extracts were evaporated to dryness under a gentle stream of nitrogen and preserved at $-18^{\circ} \mathrm{C}$ for further analysis.

\section{LC-MS/MS Quantitation}

Quantification was performed by using Multi Reaction Monitoring (MRM) mode on 6460 Triple Quad, Agilent technologies mass spectrometer (USA) coupled with reverse 
phase UPLC (1200 series infinitely Better, Agilent Technologies (USA) with thermostat, binary pump and auto-sampler at following instrumental conditions mentioned in Table 2.

Table 2. Conditions optimized for LC-MS/MS analysis.

\begin{tabular}{|c|c|c|c|}
\hline \multicolumn{2}{|c|}{ UPLC conditions } & \multicolumn{2}{|c|}{ LCMS/MS Conditions } \\
\hline Column & $\begin{array}{c}\text { XDB-C18 (Agilent } \\
\text { technologies, } 1.8 \mu \mathrm{m} \text {, } \\
2.1 \times 50 \mathrm{~mm} \text { ) }\end{array}$ & Temperature & $300^{\circ} \mathrm{C}$ \\
\hline $\begin{array}{l}\text { Mobile } \\
\text { phase }\end{array}$ & $\begin{array}{c}\mathrm{H}_{2} \mathrm{O}(0.1 \% \text { acetic } \\
\text { acid) (A) + ACN (B) }\end{array}$ & $\begin{array}{l}\text { Nebulizer } \\
\text { pressure } \\
\left(\mathrm{N}_{2}\right)\end{array}$ & $40 \mathrm{psi}$ \\
\hline Mode & $\begin{array}{c}\text { Isocratic mode, } \mathrm{ACN} \\
+\mathrm{H}_{2} \mathrm{O}(0.1 \% \text { acetic } \\
\text { acid })(1: 1)\end{array}$ & $\begin{array}{l}\text { Drying gas } \\
\text { flow }\left(\mathrm{N}_{2}\right)\end{array}$ & $9 \mathrm{~L} / \mathrm{min}$ \\
\hline Flow rate & $0.2 \mathrm{~mL} / \mathrm{min}$ & Ion source & ESI \\
\hline Run time & $5 \min$ & $\begin{array}{l}\text { Capillary } \\
\text { voltage }\end{array}$ & $4500 / 3500$ \\
\hline $\begin{array}{l}\text { Column } \\
\text { thermostat }\end{array}$ & $40{ }^{\circ} \mathrm{C}$ & $\begin{array}{l}\text { Scan range } \\
(\mathrm{m} / \mathrm{z})\end{array}$ & $50-500$ \\
\hline $\begin{array}{l}\text { Injection } \\
\text { volume }\end{array}$ & $5 \mu \mathrm{L}$ & MRM mode & $\begin{array}{l}\text { Positive/ } \\
\text { Negative }\end{array}$ \\
\hline
\end{tabular}

\section{Geomorphology of the Sampling Sites}

Sukkur formerly Aroar and Bakhar, is the 14th largest city of Pakistan. It is situated on the west bank of the Indus River and is headquarter/capital of Division and District. Modern Sukkur was built by the British general Sir Charles Napier in the 1840s. It covers an area of 5,165 square kilometers while its population is 335,551 people. The city of Sukkur is located at an altitude of 220 feet $(67 \mathrm{~m})$ from sea level, having terrestrial coordinates $68^{\circ} 52^{\prime}$ east and $27^{\circ} 42^{\prime}$ north. The main source of drinking water for peoples is river Indus. The climate of Sukkur is characterized by very hot and hazy summer with dry and cool winter $\left(10-50^{\circ} \mathrm{C}\right.$, wind speed at $10 \mathrm{~km} / \mathrm{h}, 19 \%$ humidity). Sukkur is a hub of many small and large scale industries including pharmaceuticals. It is also a center of medical activities in upper Sindh. It has a medical college, a civil hospital and many governments as well as private medical centers.

\section{Water Purification Processes Applied}

Drinking water in Sukkur was purified by simple conventional methods in two steps. First it was co-agulated by alum and secondly disinfected by chlorine. No any kind of advance technique was applied, whereas ground water taken directly without any treatment [24].

\section{Results and Discussion}

Purity Assessment of Standard Drugs by UPLC

Purity assessment of standard drugs was performed by taking their UPLC profile at following conditions. Accurately weighed 1 $\mathrm{mg}$ of standards was dissolved in $1 \mathrm{~mL}$ methanol for stock solutions then appropriately diluted with mobile phase by following serial dilutions to achieve the desired concentration. Good peak shapes were obtained (Fig. 1-3) at following instrumental conditions (Table 3) showing high purity.

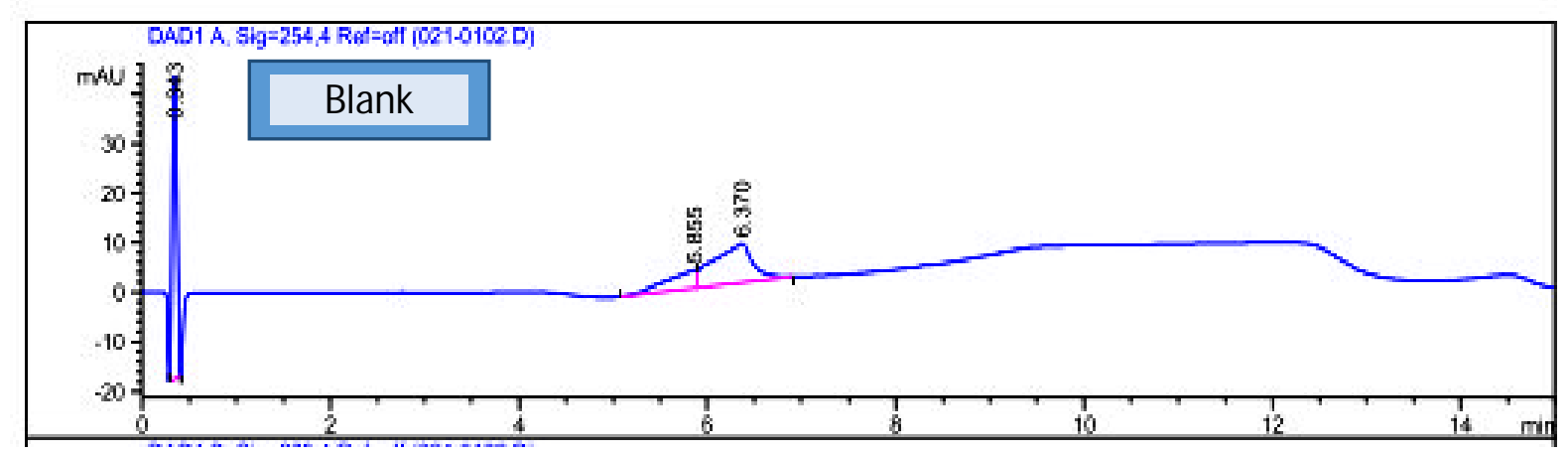

Figure 1. UPLC profile for blank 


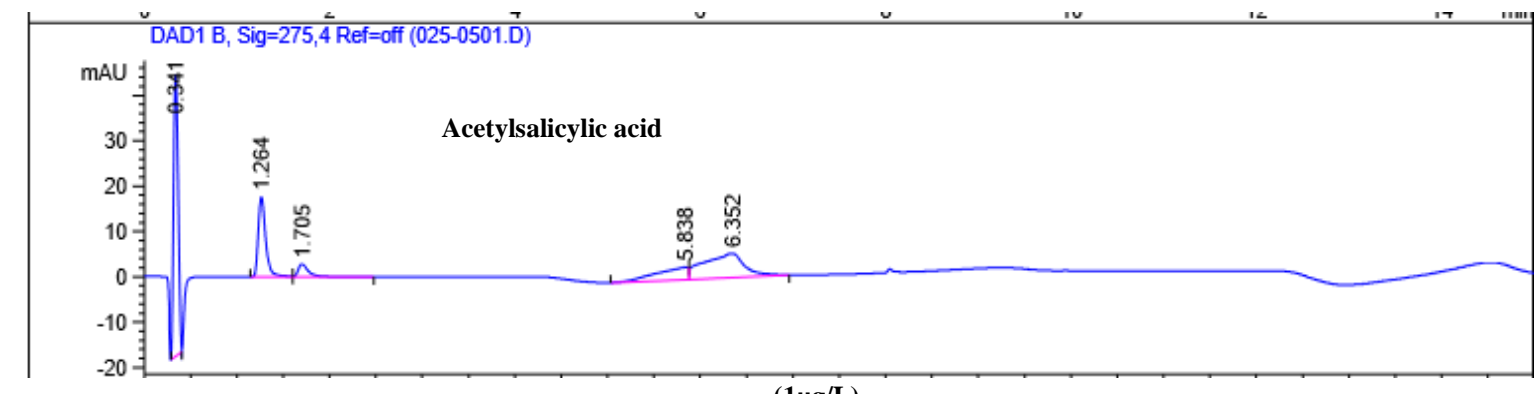

Figure 2. UPLC profile for acetylsalicylic acid

$(1 \mu \mathrm{g} / \mathrm{L})$

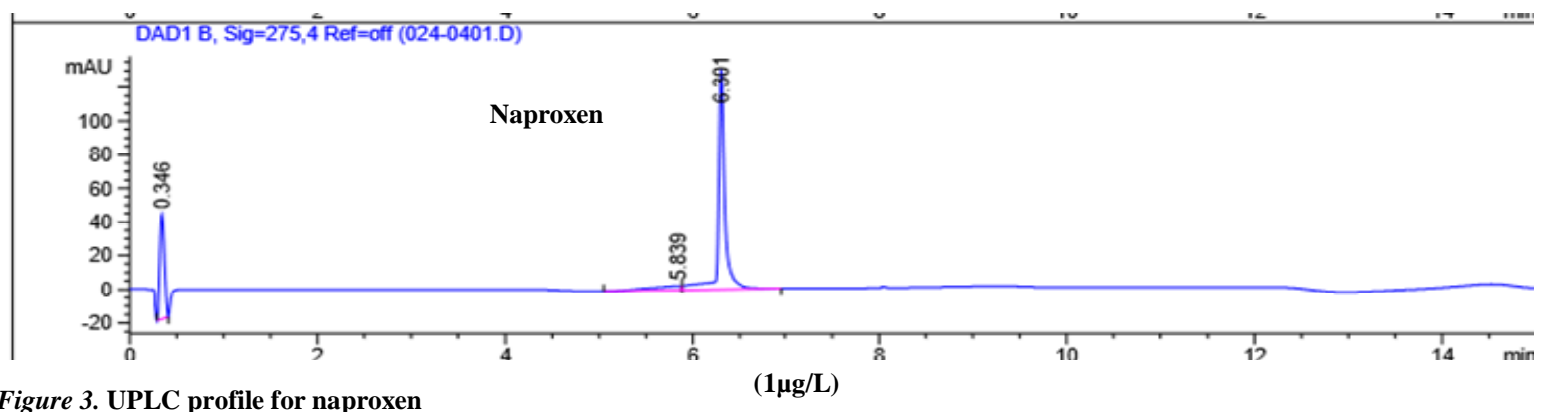

Figure 3. UPLC profile for naproxen

Table 3. Conditions optimized for UPLC analysis.

\begin{tabular}{ll}
\hline HPLC system & UPLC ultimate 3000, Agilent technologies \\
Wavelength & $235 \mathrm{~nm}, 254 \mathrm{~nm}, 275 \mathrm{~nm}$ \\
Column & Poroshell $120, \mathrm{EC}-18,2.7 \mu \mathrm{m}, 3.0,50 \mathrm{~mm}$ \\
Mobile Phase & $\mathrm{MeOH}+\mathrm{H}_{2} \mathrm{O}(0.1 \%$ formic acid $)$ \\
Flow Rate & $0.5 \mathrm{~mL} / \mathrm{min}$ \\
Injection Volume & $5 \mu \mathrm{L}$ \\
Run Time & $14 \mathrm{~min}$ \\
Gradient Mode & $\mathrm{MeOH}(10 \%-90 \%)$ Water $(90 \%-10 \%)$
\end{tabular}

\section{LC-MS/MS Analysis Method Validation}

The method linearity was established by constructing calibration curves at different concentration ns ranges from $0.5-1000 \mu \mathrm{g} / \mathrm{L}$ for each standard (Fig. 4a-4b).

The slope, regression coefficient and intercept were obtained from calibration curves. LOD and LOQ were calculated as the minimum detectable amount of the analyte with a signal-to-noise ratio of 3 and 10 , respectively. The obtained results are shown in Table 4. Acetonitrile was used as a blank and for each analyte the value of $\mathrm{R}^{2}$ was more than 0.99. One calibration standard and blank $(\mathrm{ACN})$ were measured repeatedly throughout the sequence to check the instrumental background and signal stability.

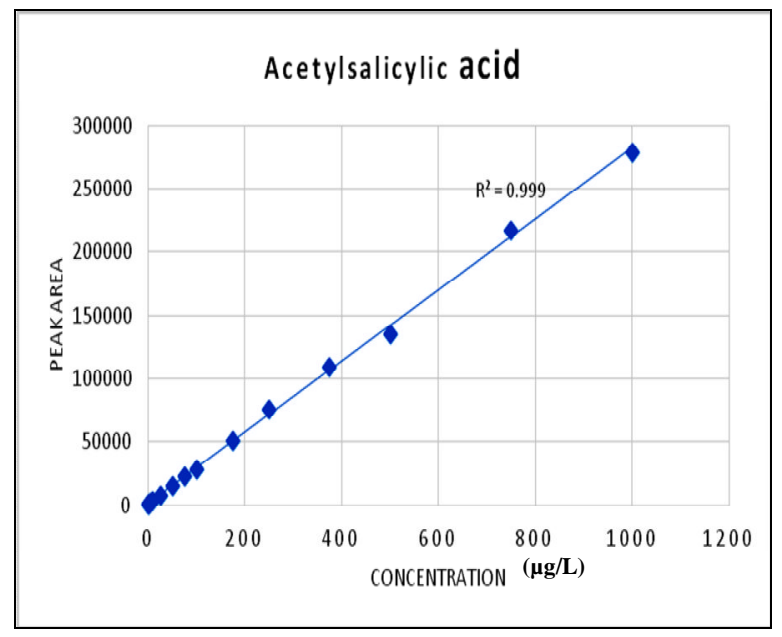

Figure 4a. Calibration curve for acetylsalicylic acid 


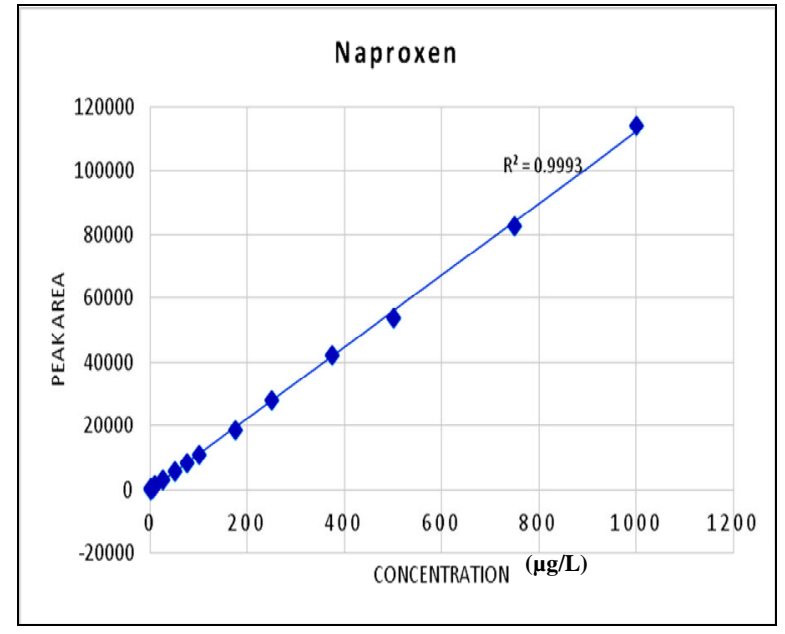

Figure $4 b$. Calibration curve for naproxen

Table 4. LOD, LOQ, slope, regression equation and regression co-efficient.

\begin{tabular}{lccccc}
\hline Analyte & $\begin{array}{c}\text { Linear } \\
\text { calibration } \\
\text { range } \\
(\boldsymbol{\mu g} / \mathbf{L})\end{array}$ & $\begin{array}{c}\text { Regression } \\
\text { equations }\end{array}$ & $\mathbf{R}^{2}$ & $\begin{array}{c}\text { LOD } \\
=\mathbf{3} \times \mathbf{S} / \mathbf{N} \\
(\boldsymbol{\mu g} / \mathbf{L})\end{array}$ & $\begin{array}{c}\mathbf{L O Q} \\
=\mathbf{1 0 \times S} / \mathbf{N} \\
(\boldsymbol{\mu g} / \mathbf{L})\end{array}$ \\
\hline $\begin{array}{l}\text { Acetylsal } \\
\text { icylic } \\
\text { acid }\end{array}$ & $0.5-1000$ & $\begin{array}{c}\mathrm{Y}=281.2 \mathrm{x}+ \\
980.21\end{array}$ & 0.999 & 0.28 & 0.84 \\
& & & & \\
Naproxen & $0.5-1000$ & $\begin{array}{c}\mathrm{Y}=112.08 \mathrm{x}- \\
96.685\end{array}$ & 0.9993 & 0.84 & 2.55 \\
\hline
\end{tabular}

\section{Method Precision}

It was determined by intra-day and inter-day repeated analysis and expressed as relative standard deviation percentage (RSD $\%)$ and accuracy (\%) in Table 5. Three standard mixtures of analytes at concentration of 125,250 and $500 \mu \mathrm{g} / \mathrm{L}$ and six successive injections in one day and six consecutive days in triplicate were used, respectively. RSD for intra-day analysis was $0.99-2.1 \%$ and 1.3 $2.3 \%$, whereas inter-day analysis was $1.0-1$. $3 \%$ and $0.9-3.5 \%$ for acetylsalicylic acid and naproxen, respectively.

Table 5. Inter-day and intra-day precision of acetylsalicylic acid and naproxen .

\begin{tabular}{|c|c|c|c|c|c|c|c|}
\hline \multirow[b]{2}{*}{ Drugs } & \multirow{2}{*}{$\begin{array}{c}\text { Concent- } \\
\text { rations } \\
(\mu \mathrm{g} / \mathrm{L})\end{array}$} & \multicolumn{3}{|c|}{ Intra-day } & \multicolumn{3}{|c|}{ Inter-day } \\
\hline & & $\begin{array}{l}\text { Found } \\
(\mu \mathrm{g} / \mathrm{L})\end{array}$ & $\begin{array}{c}\text { RSD } \\
(\%)\end{array}$ & $\begin{array}{c}\text { Accuracy } \\
(\%)\end{array}$ & $\begin{array}{l}\text { Found } \\
(\mu \mathrm{g} / \mathrm{L})\end{array}$ & $\begin{array}{c}\text { RSD } \\
(\%)\end{array}$ & $\begin{array}{c}\text { Accuracy } \\
(\%)\end{array}$ \\
\hline \multirow{3}{*}{$\begin{array}{l}\text { Acetyl- } \\
\text { salicylic } \\
\text { acid }\end{array}$} & 125 & 126.4 & 0.99 & 101.1 & 126.9 & 1.3 & 101.5 \\
\hline & 250 & 252.1 & 1.9 & 100.8 & 251.7 & 2.0 & 100.7 \\
\hline & 500 & 498.3 & 2.1 & 99.7 & 498.6 & 1.0 & 99.7 \\
\hline \multirow{3}{*}{ Naproxen } & 125 & 127.3 & 1.6 & 101,8 & 126.5 & 1.1 & 101.2 \\
\hline & 250 & 251.8 & 1.3 & 100.7 & 251.3 & 0.9 & 100.5 \\
\hline & 500 & 496.7 & 2.3 & 99.3 & 495.1 & 3.5 & 99.0 \\
\hline
\end{tabular}

\section{LC-MS/MS Optimization}

For quantitative analysis Agilent mass hunter software was used to optimize the parameters like collision energy (CE) and fragmentor voltage $(\mathrm{FV})$ etc. mentioned in the Table 6. Multiple Reaction Monitoring (MRM) mode applied was negative ion mode. The most abundant fragment was selected for quantitative analysis (Fig. 6a-8).

Table 6. Parameters optimized for LC-MS/MS analysis.

\begin{tabular}{|c|c|c|c|c|c|c|c|}
\hline $\begin{array}{l}\text { Reference } \\
\text { Compounds }\end{array}$ & $\begin{array}{l}\text { Retention time } \\
\text { (min) }\end{array}$ & $\begin{array}{l}\text { Precursor } \\
\text { Type }\end{array}$ & $\begin{array}{l}\text { Precursor } \\
(m / z)\end{array}$ & $\begin{array}{c}\text { MS/MS transitions } \\
(\mathrm{m} / \mathrm{z})\end{array}$ & $\begin{array}{l}\text { Fragmentor } \\
\text { Voltage }\end{array}$ & $\begin{array}{l}\text { Collision } \\
\text { Energy }\end{array}$ & $\begin{array}{l}\text { Dwell } \\
\text { Time }\end{array}$ \\
\hline $\begin{array}{l}\text { Acetylsalicylic } \\
\text { acid }\end{array}$ & 1.563 & $\begin{array}{c}{[\mathrm{M}-\mathrm{H}]^{-}} \\
\text {-ve mode }\end{array}$ & 179 & 179--> 137 & 60 & 2 & 50 \\
\hline Naproxen & 2.264 & $\begin{array}{c}{[\mathrm{M}-\mathrm{H}]^{-}} \\
\text {-ve mode }\end{array}$ & 229 & 229 ---> 185 & 80 & 5 & 50 \\
\hline
\end{tabular}




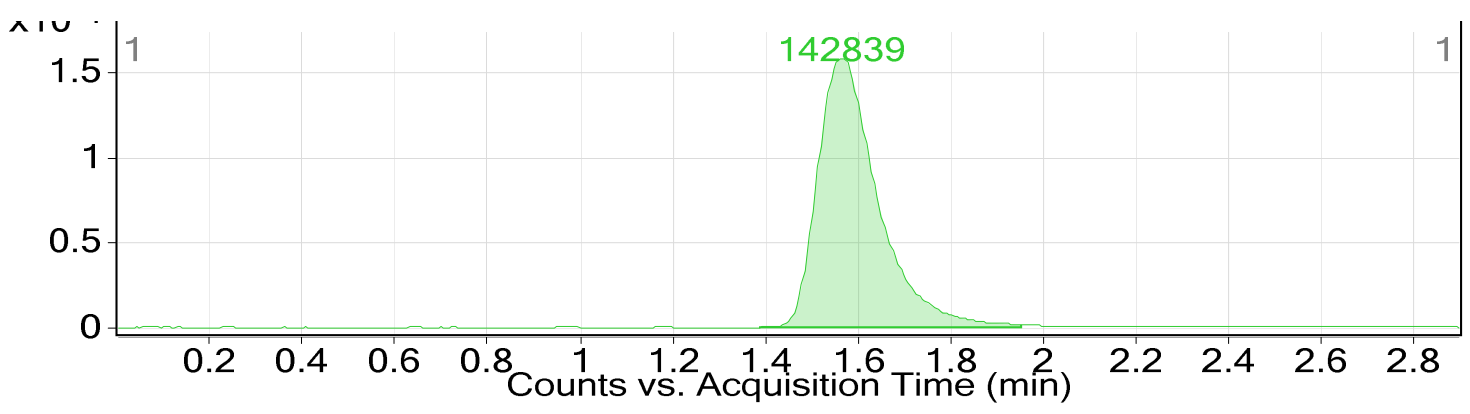

Figure 6a. MRM chromatogram

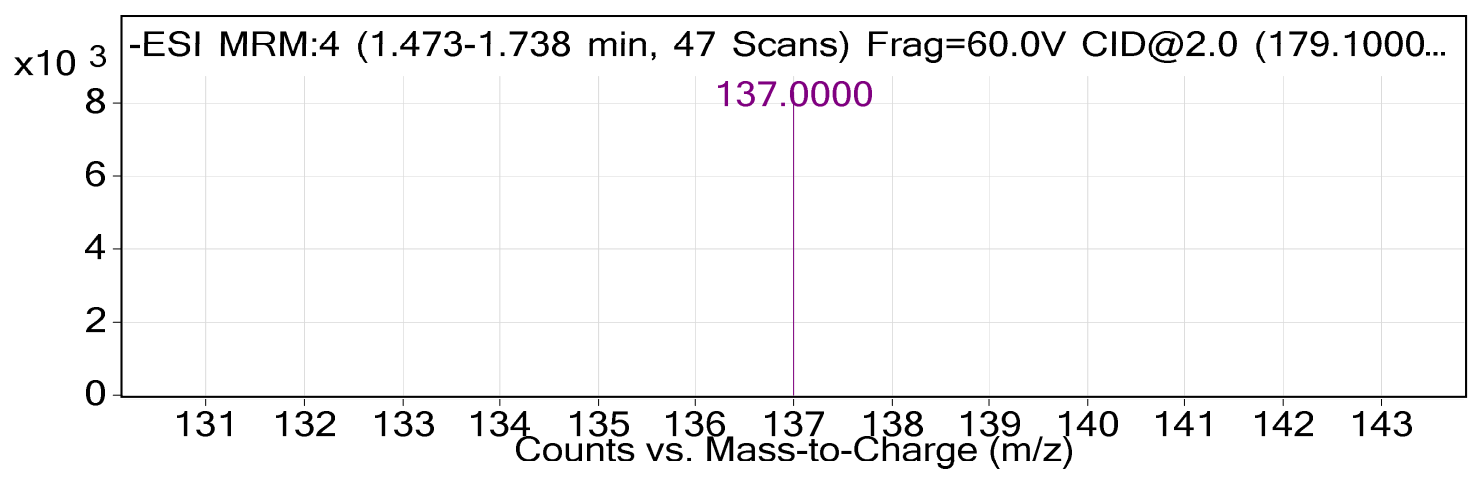

Figure 6 b. LCMS/MS transition for acetylsalicylic acid

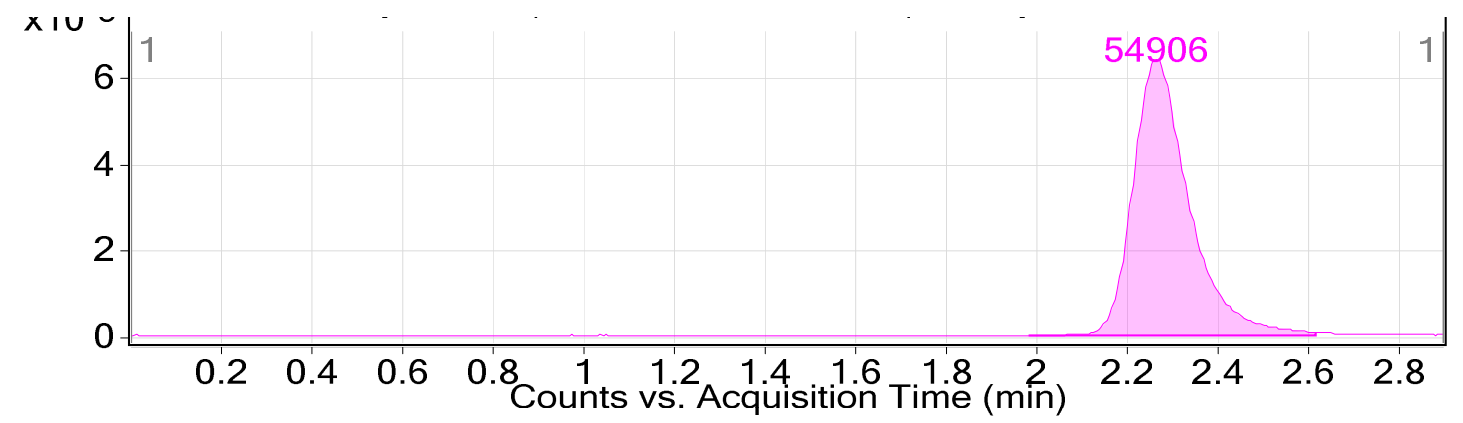

Figure 7a. MRM chromatogram for naproxen

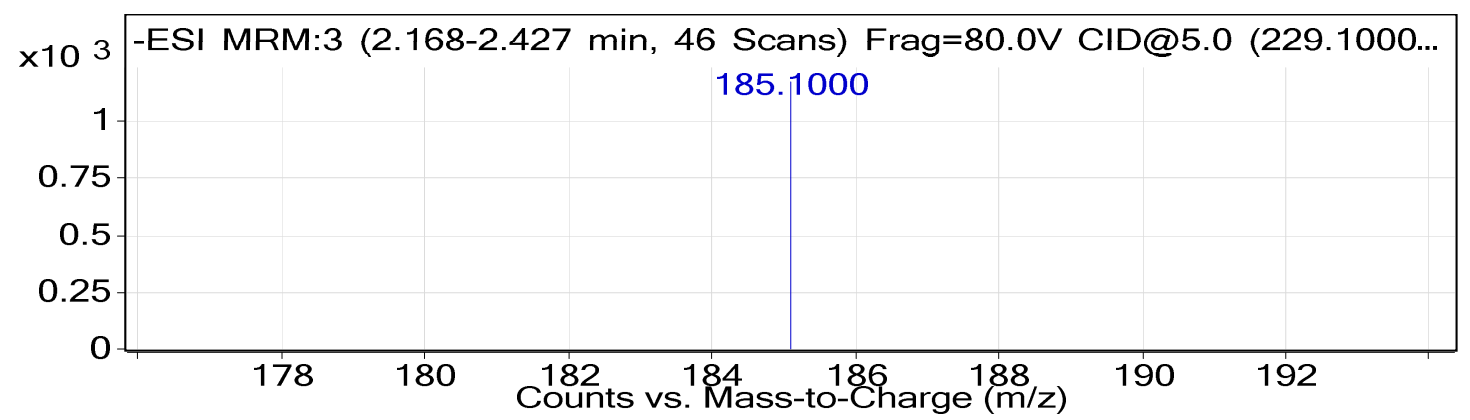

Figure $7 b$. MS/MS transition for naproxen 


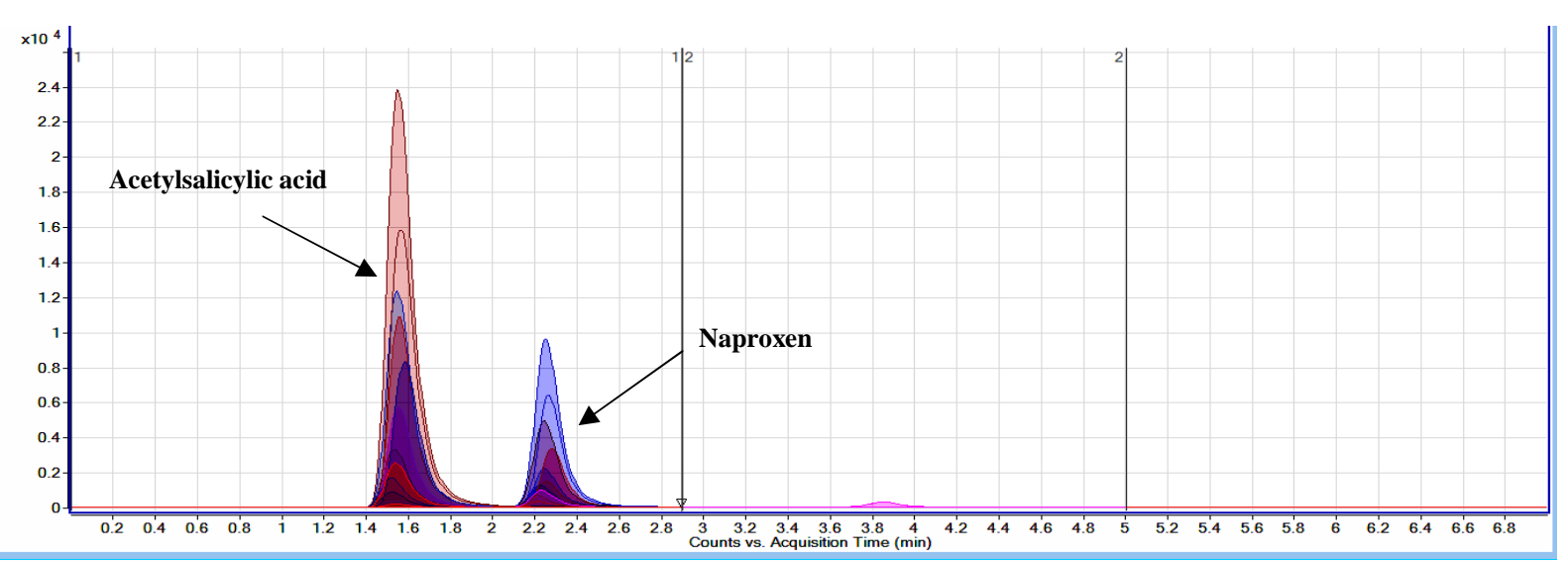

Figure 8. MRM chromatograms of acetylsalicylic acid and naproxen

Pharmaceuticals Detection in Waste and Tap Water

The results indicated that both pharmaceuticals naproxen and acetylsalicylic acid were present in waste as well as tap water samples Table 7-8 and Fig. 9-12. The concentration of acetylsalicylic acid ranges between $7.38-190.06 \mu \mathrm{g} / \mathrm{L}$ in waste water while 5.47-62.27 $\mu \mathrm{g} / \mathrm{L}$ in tap water. At only one site similar detections were found from not detected $1.3 \mu \mathrm{g} / \mathrm{L}$ for acetylsalicylic acid in the water of the Umgeni river system in South Africa [33]. Among 20 samples it was present in all sites except W4 where it was below detection limit (BDL). In tap water, it was detected in all samples where as it was below detection limit in 6 samples (T3, T4, T5, T14, T17 and T20).

Naproxen has been found comparatively in greater concentration ranging from 26.80-827.61 $\mu \mathrm{g} / \mathrm{L}$ and 8.96-328.95 $\mu \mathrm{g} / \mathrm{L}$ in waste and tap water, respectively. Concentration of naproxen in waste water mentioned in Table 7 is in accordance with findings in influent and effluent from wastewater treatment plants (WWTPs) at France from $0.26-23.21 \mu \mathrm{g} / \mathrm{L}$ [26], at WWTPs of South Africa, from $15-20 \mu \mathrm{g} / \mathrm{L}$ [27] and in municipal waste effluents of Pachuca, Mexico from 20$47 \mu \mathrm{g} / \mathrm{L}$ [28]. Same drug was found in an
Umgeni river system of South Africa up to $59.3 \mu \mathrm{g} / \mathrm{L}$ concentration [29]. The observed concentrations of the target pharmaceuticals in this study are in agreement with reported data in the literature [30-32].

Table 7. Concentration of naproxen in waste and tap water samples.

\begin{tabular}{|c|c|c|c|}
\hline \multicolumn{2}{|c|}{ Naproxen in wastewater } & \multicolumn{2}{|c|}{ Naproxen in tap water } \\
\hline $\begin{array}{l}\text { Sample } \\
\text { Number }\end{array}$ & $\begin{array}{c}\text { Concentration } \\
(\mu g / L)\end{array}$ & $\begin{array}{c}\text { Sample } \\
\text { Number }\end{array}$ & $\begin{array}{c}\text { Concentration } \\
(\mu g / L)\end{array}$ \\
\hline W1 & 115.46 & $\mathrm{~T} 1$ & 31.21 \\
\hline $\mathrm{W} 2$ & 255.73 & $\mathrm{~T} 2$ & 13.96 \\
\hline W3 & 26.80 & $\mathrm{~T} 3$ & 14.02 \\
\hline W4 & 479.79 & $\mathrm{~T} 4$ & 328.95 \\
\hline W5 & 266.16 & T5 & 126.49 \\
\hline W6 & 244.10 & T6 & 55.211 \\
\hline W7 & 377.25 & $\mathrm{~T} 7$ & 327.49 \\
\hline W8 & 41.43 & $\mathrm{~T} 8$ & 27.2 \\
\hline W9 & 75.09 & T9 & 8.96 \\
\hline W10 & 54.71 & $\mathrm{~T} 10$ & 14.02 \\
\hline W11 & 601.64 & $\mathrm{~T} 11$ & 65.31 \\
\hline $\mathrm{W} 12$ & 148.10 & $\mathrm{~T} 12$ & 26.05 \\
\hline W13 & 681.09 & $\mathrm{~T} 13$ & 123.38 \\
\hline W14 & 537.55 & $\mathrm{~T} 14$ & 141.89 \\
\hline W15 & 76.56 & $\mathrm{~T} 15$ & 25.78 \\
\hline W16 & 827.61 & T16 & 28.74 \\
\hline W17 & 114.39 & T17 & 97.96 \\
\hline W18 & 119.78 & $\mathrm{~T} 18$ & 99.98 \\
\hline W19 & 91.42 & $\mathrm{~T} 19$ & 37.33 \\
\hline W20 & 254.69 & $\mathrm{~T} 20$ & 34.28 \\
\hline
\end{tabular}




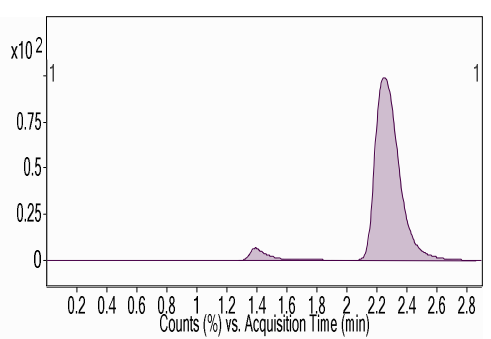

\section{W1 Sample}

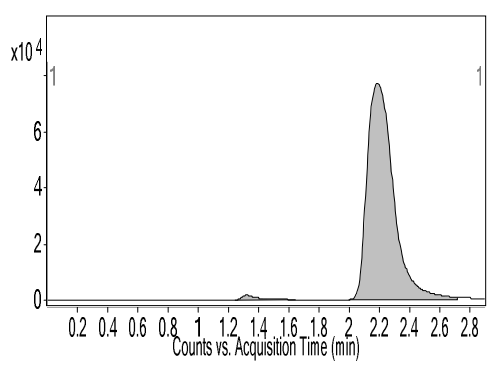

W5 Sample

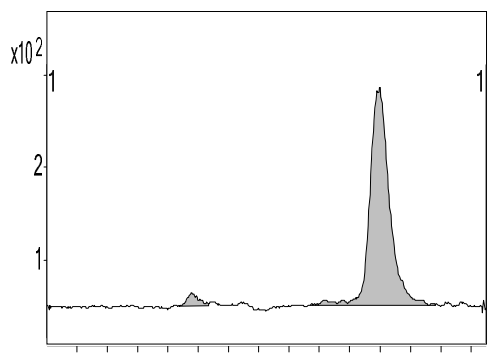

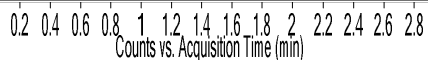

W11 Sample

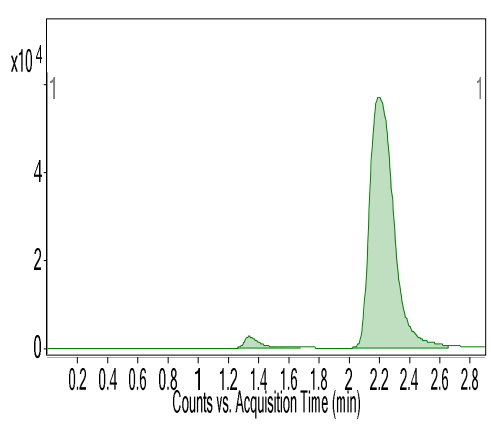

W14 Sample

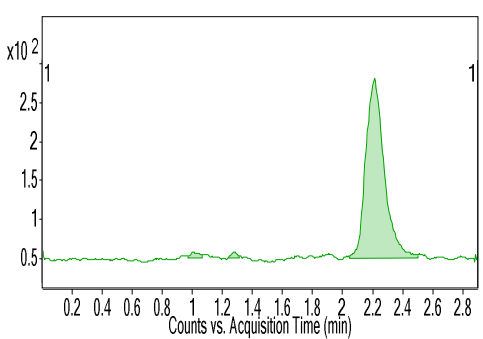

W2 Sample

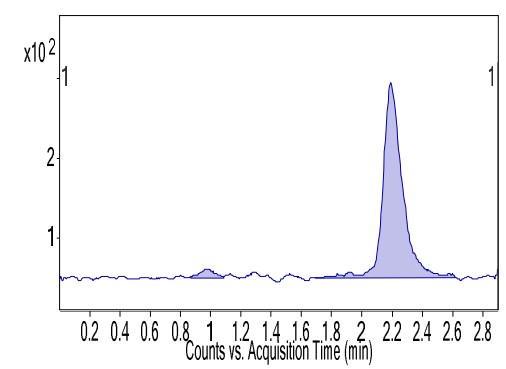

W6 Sample

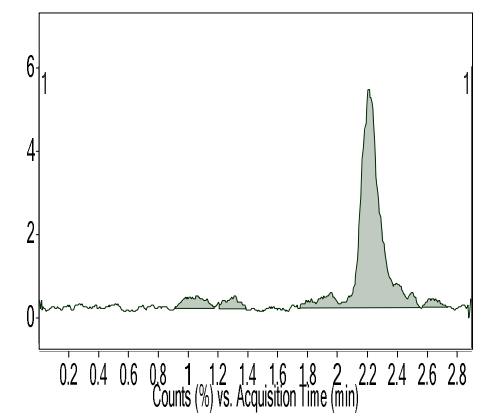

W12 Sample

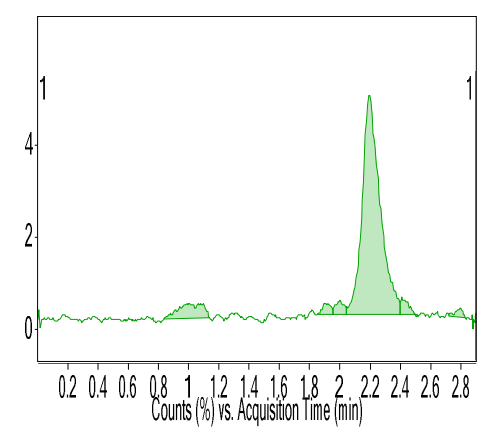

W16 Sample

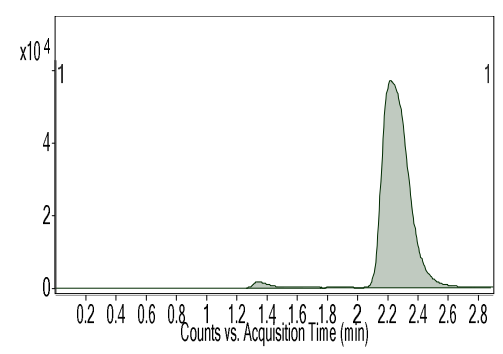

W4 Sample

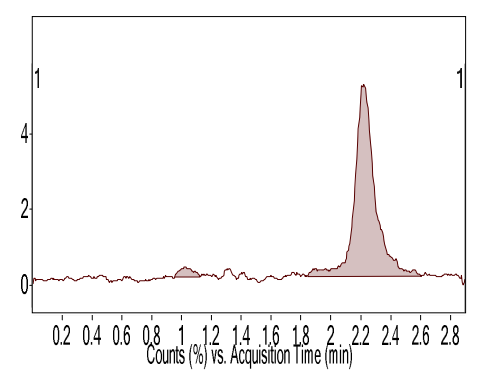

W7 Sample

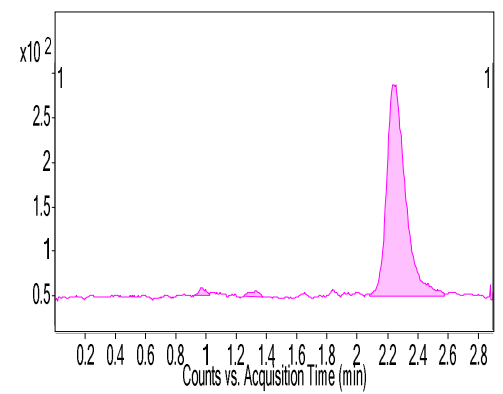

W13 Sample

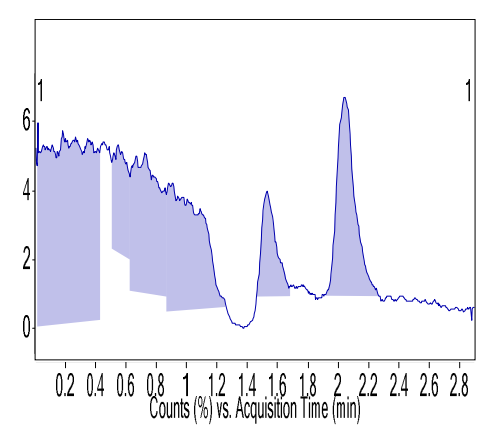

W16 Sample

Figure 9. MRM chromatograms of naproxen in waste water 


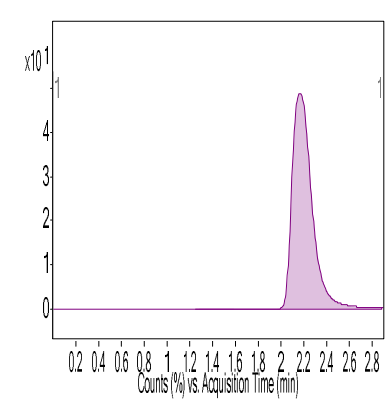

T1 Sample

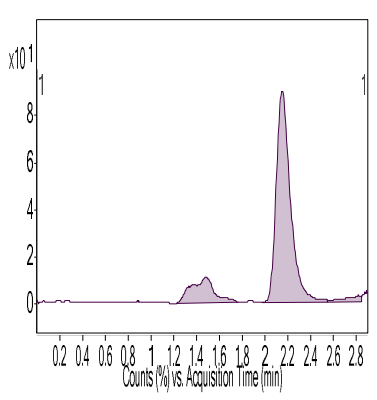

T5 Sample

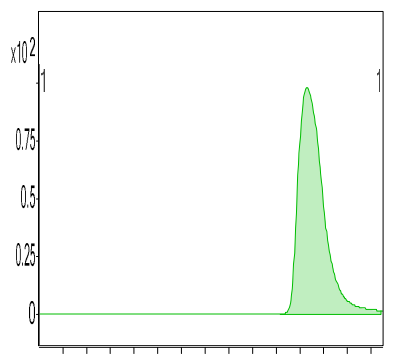

0204068081121416182222242628

\section{T9 Sample}

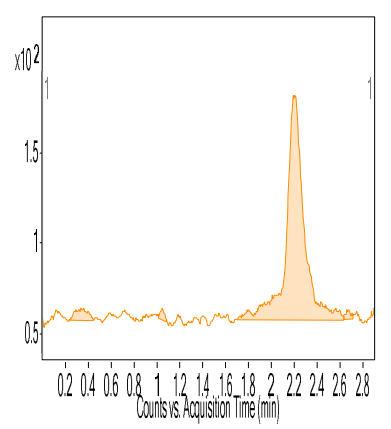

T3 Sample

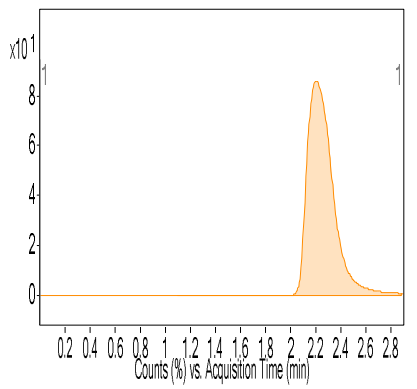

T2 Sample

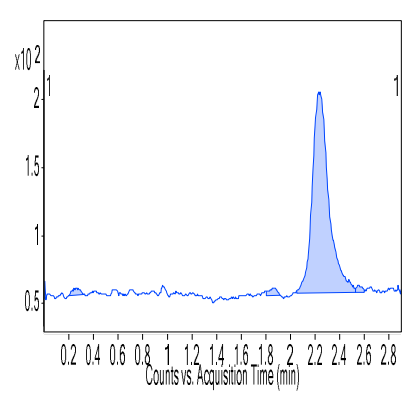

T6 Sample

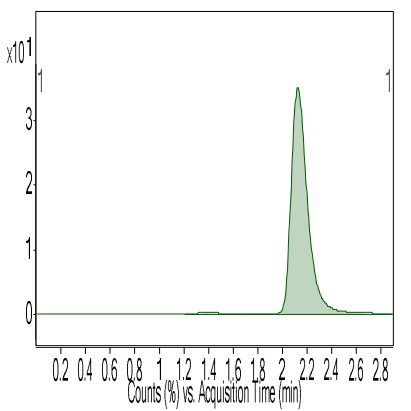

T10 Sample

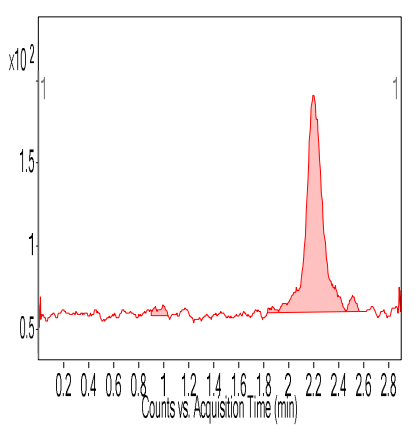

T4 Sample

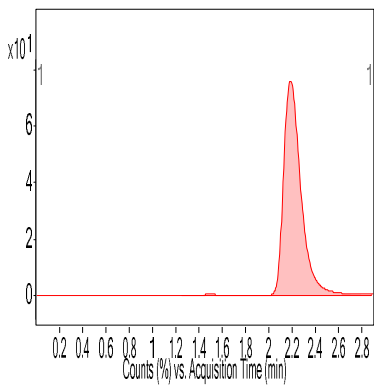

T3 Sample

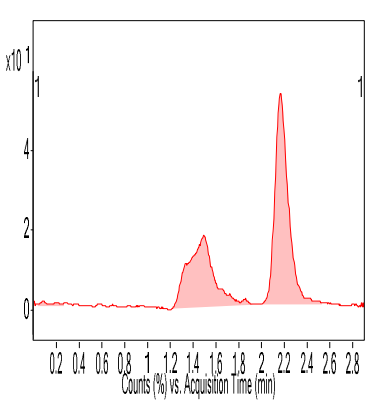

T7 Sample

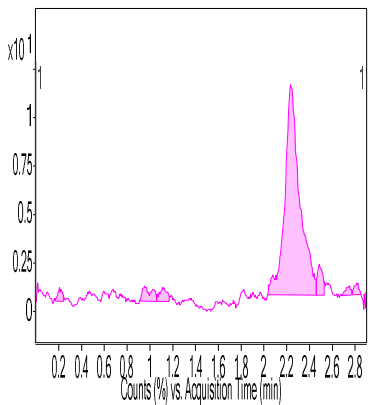

T11 Sample

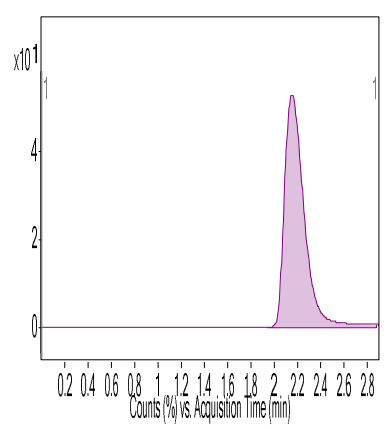

T5 Sample

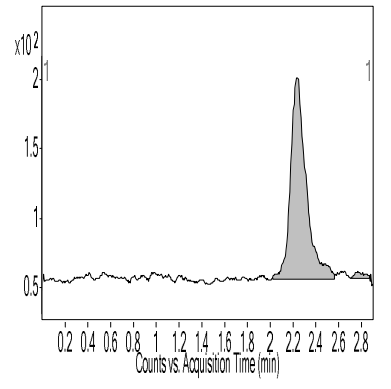

T4 Sample

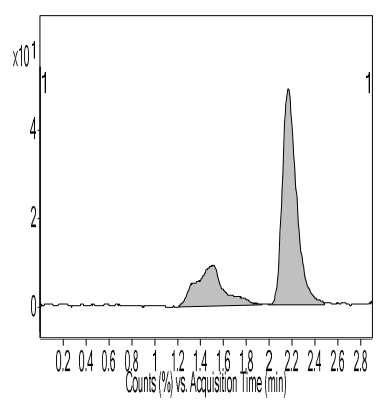

T8 Sample

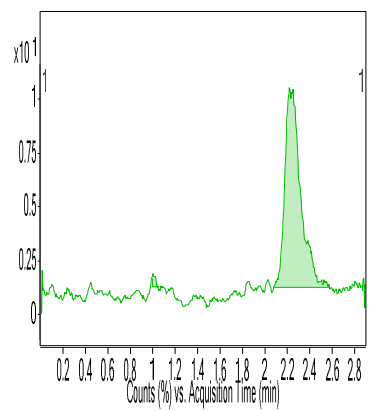

T12 Sample

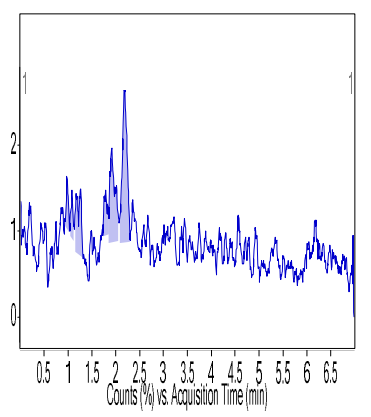

T6 Sample

Figure 10. MRM chromatograms for naproxen in tap water samples 


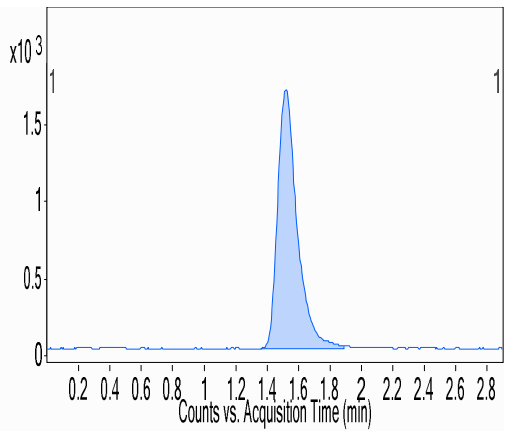

W1 Sample

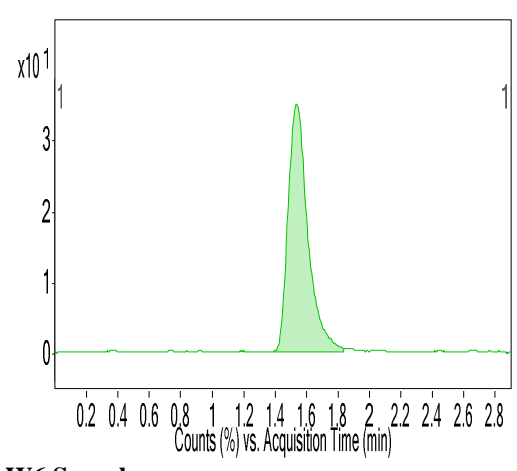

\section{W6 Sample}

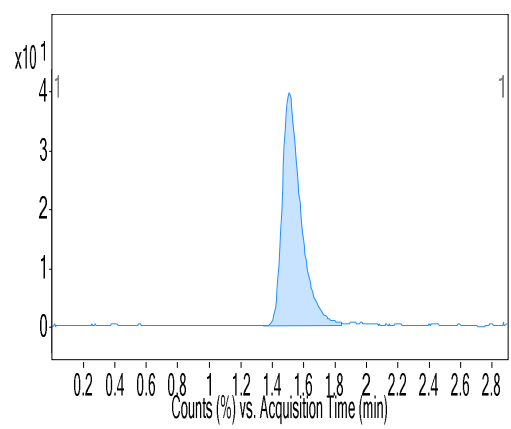

W9 Sample

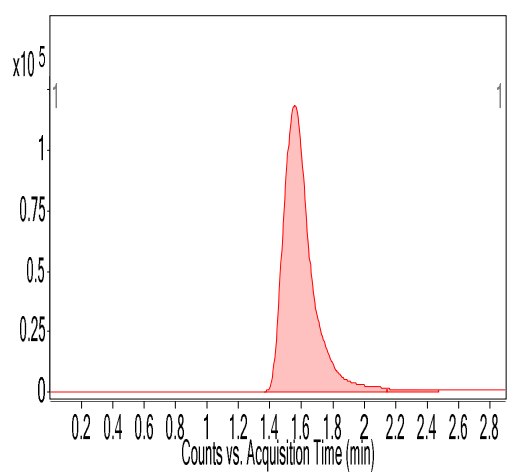

W14 Sample

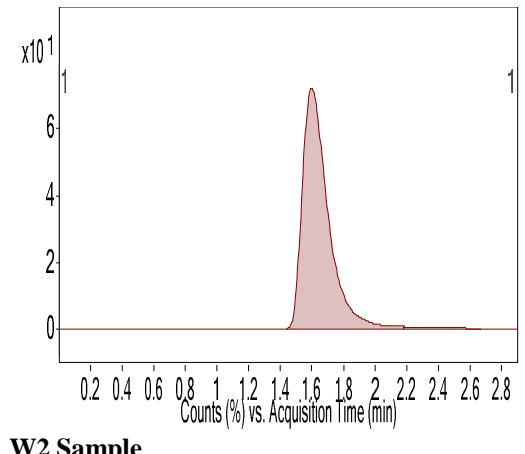

W2 Sample

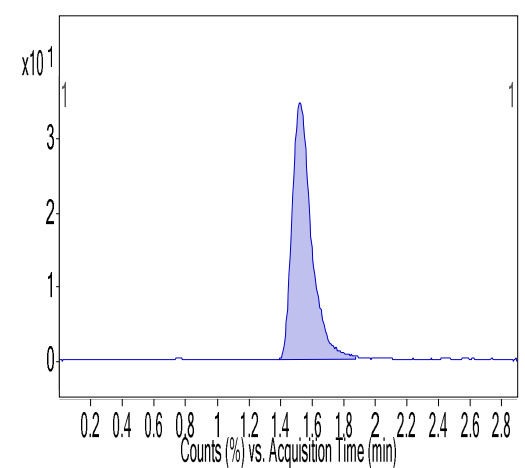

W7 Sample

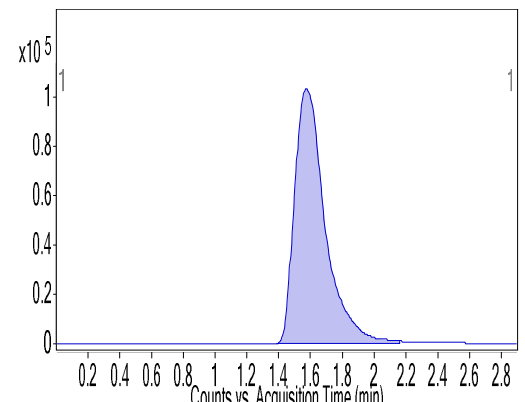

W10 Sample

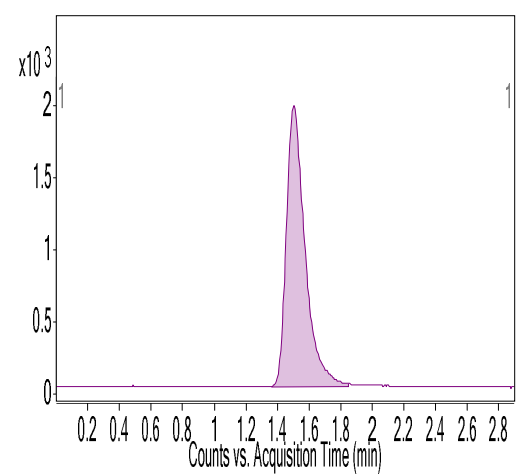

W16 Sample

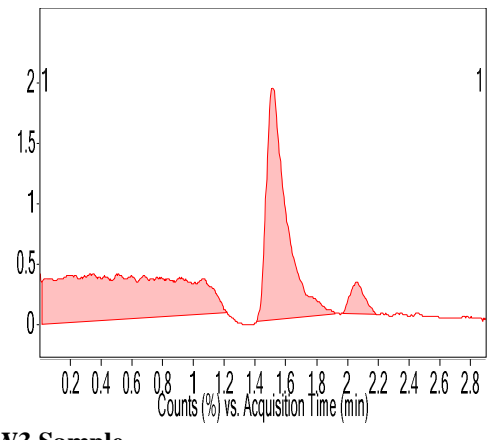

W3 Sample

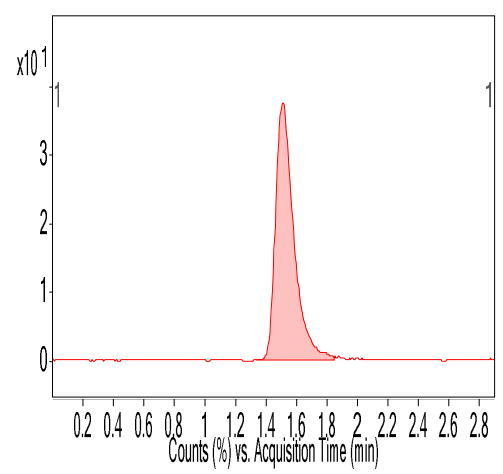

W8 Sample

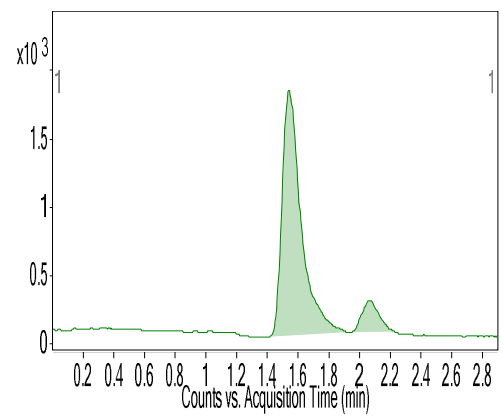

W13 Sample

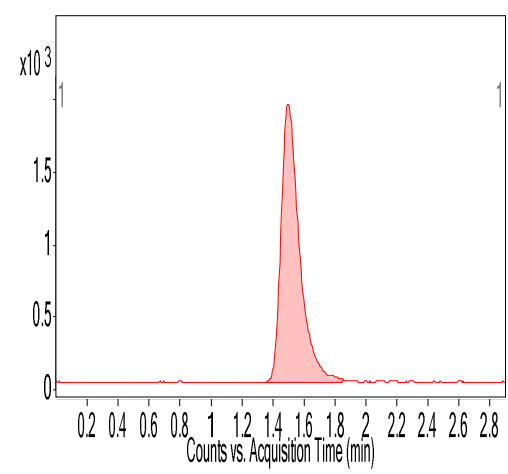

W19 Sample

Figure 11. MRM chromatograms of acetylsalicylic acid in wastewater samples 
Pak. J. Anal. Environ. Chem. Vol. 21, No. 2 (2020)

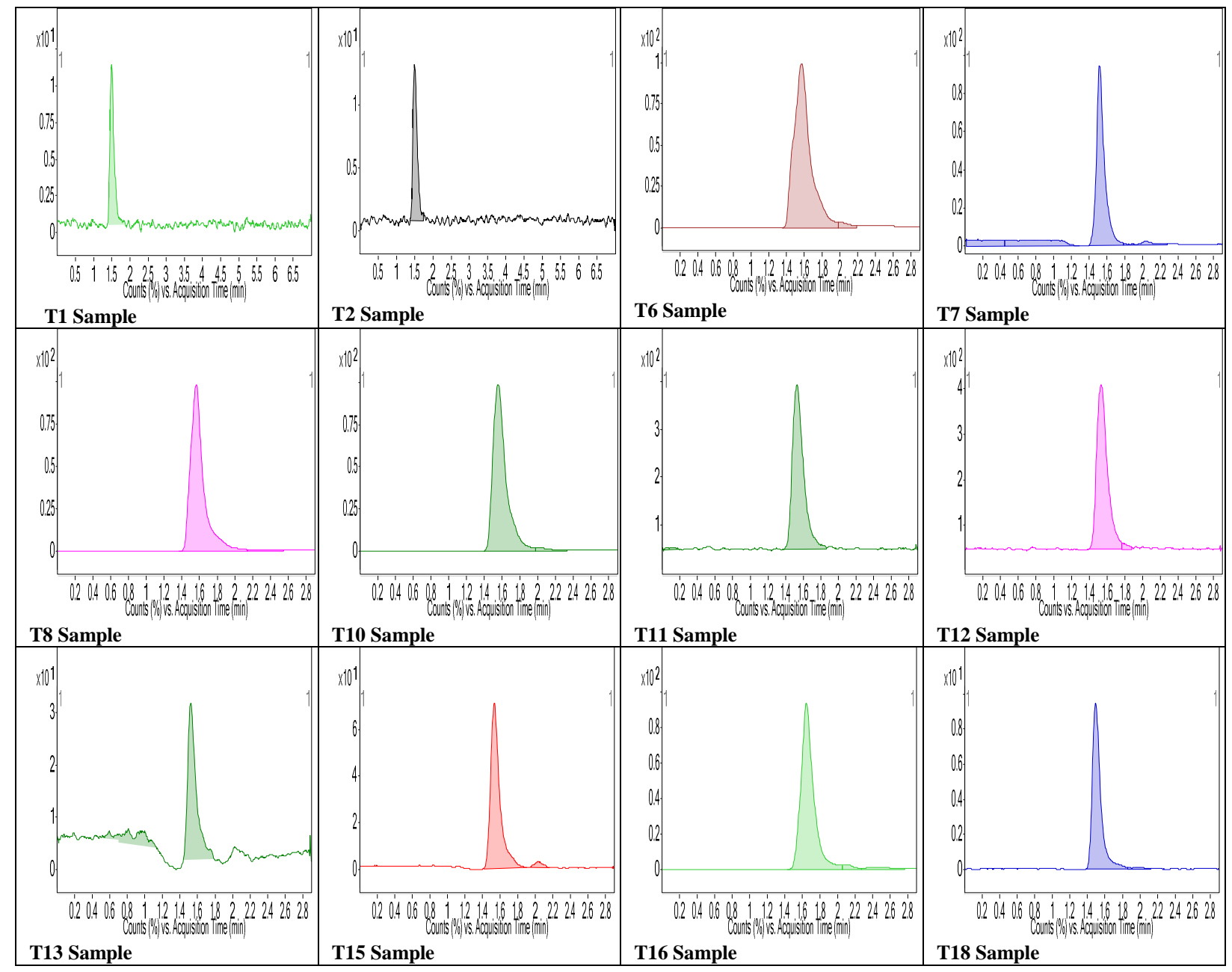

Figure 12. MRM chromatograms for acetylsalicylic acid in tap water samples

Table 8. Concentration of acetylsalicylic acid in waste and tap water samples.

\begin{tabular}{|c|c|c|c|}
\hline \multicolumn{2}{|c|}{ Acetylsalicylic acid in wastewater } & \multicolumn{2}{|c|}{ Acetylsalicylic acid in tap water } \\
\hline Sample Number & Concentration $(\mu g / L)$ & Sample Number & Concentration $(\mu g / L)$ \\
\hline $\mathrm{W} 1$ & 99.79 & $\mathrm{~T} 1$ & 62.27 \\
\hline W2 & 75.64 & $\mathrm{~T} 2$ & 56.90 \\
\hline W3 & 51.24 & $\mathrm{~T} 3$ & BDL \\
\hline W4 & BDL & $\mathrm{T} 4$ & BDL \\
\hline W5 & 7.38 & $\mathrm{~T} 5$ & BDL \\
\hline W6 & 52.48 & T6 & 8.55 \\
\hline W7 & 83.09 & $\mathrm{~T} 7$ & 30.85 \\
\hline W8 & 108.16 & $\mathrm{~T} 8$ & 7.42 \\
\hline W9 & 190.06 & Т9 & ND \\
\hline W10 & 186.89 & $\mathrm{~T} 10$ & 10.1 \\
\hline W11 & 8.12 & $\mathrm{~T} 11$ & 5.47 \\
\hline W12 & 7.35 & $\mathrm{~T} 12$ & 6.76 \\
\hline W13 & 12.02 & $\mathrm{~T} 13$ & 6.80 \\
\hline W14 & 23.29 & $\mathrm{~T} 14$ & BDL \\
\hline W15 & 22.63 & $\mathrm{~T} 15$ & 9.15 \\
\hline W16 & 48.01 & T16 & 8.12 \\
\hline W17 & 24.83 & $\mathrm{~T} 17$ & BDL \\
\hline W18 & 25.12 & T18 & 6.49 \\
\hline W19 & 52.85 & T19 & ND \\
\hline W20 & 7.81 & T20 & BDL \\
\hline
\end{tabular}




\section{Risk Assessment}

Risk assessment can be calculated by many ways but the most common and reliable method is to measure, Risk Quotient (RQ) value by using Minimum Therapeutic Dose (MTD) of drugs [33].

\section{$\mathrm{RQ}=\mathrm{Cm} 2 / \mathrm{MTD} \times 10^{3}$ where} $\mathrm{Cm}=$ measured concentration in $\mu \mathrm{g} / \mathrm{L}$ [34].

RQ value of both drugs (Table 9-10) is $<<1$ (order of $10^{-3}-10^{-5}$ ) in all samples indicating No observed adverse effect level (NOAEL) but it will contribute to combined water matrix effect, however continuous intake of these drugs combined with other drugs may be harmful and longtime use even in minor quantities may pose a serious risk to humans health [35].

Table 9. Risk Quotient values of naproxen.

\begin{tabular}{|c|c|c|c|}
\hline \multirow{2}{*}{$\begin{array}{c}\text { Sample } \\
\text { code }\end{array}$} & \multicolumn{3}{|c|}{ Naproxen in tap water } \\
\hline & $\begin{array}{c}\text { Measured Conc. } \\
(\mu \mathrm{g} / \mathrm{L})\end{array}$ & RQ value & Remarks \\
\hline $\mathrm{T} 1$ & 31.21 & $2.4 \times 10^{-4}$ & *NOAEL \\
\hline $\mathrm{T} 2$ & 13.96 & $1.1 \times 10^{-4}$ & NOAEL \\
\hline $\mathrm{T} 3$ & 14.02 & $1.1 \times 10^{-4}$ & NOAEL \\
\hline $\mathrm{T} 4$ & 328.95 & $2.6 \times 10^{-3}$ & NOAEL \\
\hline $\mathrm{T} 5$ & 126.49 & $1.0 \times 10^{-3}$ & NOAEL \\
\hline T6 & 55.211 & $4.4 \times 10^{-4}$ & NOAEL \\
\hline $\mathrm{T} 7$ & 327.49 & $2.6 \times 10^{-3}$ & NOAEL \\
\hline $\mathrm{T} 8$ & 27.2 & $2.1 \times 10^{-4}$ & NOAEL \\
\hline T9 & 8.96 & $7.1 \times 10^{-5}$ & NOAEL \\
\hline $\mathrm{T} 10$ & 14.02 & $1.1 \times 10^{-4}$ & NOAEL \\
\hline $\mathrm{T} 11$ & 65.31 & 5. $2 \times 10^{-4}$ & NOAEL \\
\hline $\mathrm{T} 12$ & 26.05 & $2.0 \times 10^{-4}$ & NOAEL \\
\hline $\mathrm{T} 13$ & 123.38 & $9.8 \times 10^{-4}$ & NOAEL \\
\hline $\mathrm{T} 14$ & 141.89 & $1.1 \times 10^{-3}$ & NOAEL \\
\hline $\mathrm{T} 15$ & 25.78 & $2.0 \times 10^{-4}$ & NOAEL \\
\hline T16 & 28.74 & $2.2 \times 10^{-4}$ & NOAEL \\
\hline $\mathrm{T} 17$ & 97.96 & $7.8 \times 10^{-4}$ & NOAEL \\
\hline $\mathrm{T} 18$ & 99.98 & $7.9 \times 10^{-4}$ & NOAEL \\
\hline T19 & 37.33 & $2.9 \times 10^{-4}$ & NOAEL \\
\hline $\mathrm{T} 20$ & 34.28 & $2.7 \times 10^{-4}$ & NOAEL \\
\hline
\end{tabular}

Table 10. Risk Quotient values of acetylsalicylic acid.

\begin{tabular}{|c|c|c|c|}
\hline \multirow[b]{2}{*}{$\begin{array}{c}\text { Sample } \\
\text { code }\end{array}$} & \multicolumn{3}{|c|}{ Acetylsalicylic acid in tap water } \\
\hline & $\begin{array}{c}\text { Measured } \\
\text { Conc. } \\
(\mu \mathrm{g} / \mathrm{L}) \\
\end{array}$ & RQ value & Remarks \\
\hline $\mathrm{T} 1$ & 62.27 & 4. $1 \times 10^{-3}$ & NOAEL \\
\hline $\mathrm{T} 2$ & 56.90 & $3.7 \times 10^{-3}$ & NOAEL \\
\hline T3 & BDL* & BDL & NOAEL \\
\hline T4 & BDL & BDL & NOAEL \\
\hline T5 & BDL & BDL & NOAEL \\
\hline T6 & 8.55 & 2. $2 \times 10^{-3}$ & NOAEL \\
\hline $\mathrm{T} 7$ & 30.85 & 2. $0 \times 10^{-3}$ & NOAEL \\
\hline $\mathrm{T} 8$ & 7.42 & 2. $6 \times 10^{-3}$ & NOAEL \\
\hline T9 & ND* & ND & NOAEL \\
\hline T10 & 10.91 & 1. $2 \times 10^{-3}$ & NOAEL \\
\hline T11 & 5.47 & 1. $4 \times 10^{-3}$ & NOAEL \\
\hline T12 & 6.76 & 4. $5 \times 10^{-3}$ & NOAEL \\
\hline $\mathrm{T} 13$ & 6.80 & 4. $5 \times 10^{-3}$ & NOAEL \\
\hline T14 & BDL & BDL & NOAEL \\
\hline T15 & 9.15 & 2. $4 \times 10^{-3}$ & NOAEL \\
\hline T16 & 8.12 & 2. $7 \times 10^{-3}$ & NOAEL \\
\hline T17 & BDL & BDL & NOAEL \\
\hline T18 & 6.49 & $1.7 \times 10^{-3}$ & NOAEL \\
\hline T19 & ND & ND & NOAEL \\
\hline T20 & BDL & BDL & NOAEL \\
\hline
\end{tabular}

*Where NOAEL $=$ No observed adverse effect level

\section{Conclusions}

SPE-LC-MS/MS technique has been successfully applied for the detection and quantification of naproxen and acetylsalicylic acid to check their impacts on the environment. Both pharmaceuticals were found in waste and tap water sources of municipal area of Sukkur city. Naproxen was found comparatively in higher concentration range 26.80 to $827.61 \mu \mathrm{g} / \mathrm{L}$ and 8.96 to 328.95 $\mu \mathrm{g} / \mathrm{L}$, while low concentration of Acetylsalicylic acid was observed ranges 
between 7.38 to $190.06 \mu \mathrm{g} / \mathrm{L}$ and 5.47 to $62.27 \mu \mathrm{g} / \mathrm{L}$ in waste and tap water samples respectively. The results obtained are comparable with the data reported in literature. Human health risk was assessed by Risk Quotient approach. The calculated values regarding risk factor were substantially low to cause any harm to the consumer's health but may pose a danger synergistically.

\section{References}

1. S. Bibi, R. L. Khan, R. Nazir, P. Khan, H. U. Rehman, S. K. Shakir, S. Naz, M. A. Waheed and R. Jan, World Appl. Sci. J., 34 (2016) 15. https://doi:10.5829/idosi.wasj.2016.34.1. $\underline{10252}$

2. Q. Sun, M. Li, C. Ma, X. Chen, X. Xie, and C. P. Yu, Environ. Pollut., 208 (2016) 371.

https://doi.org/10.1016/j.envpol.2015.10. $\underline{003}$

3. S. Alrumman, S. Keshk and A. El Kott. Amer. J. Environ. Eng., 6 (2016) 88.

https://doi: 10.5923/j.ajee.20160603.02

4. M. J. Pawari and S. Gawande. Int. J. Eng. Res. Gen. Sci., 3 (2015) 773. https://doi: 10.12691/jephh-6-3-2.

5. S. M. Kamble, Int. J. Sci. Res. Pubs, 4 (2014) 1.

https://doi:10.1.1.429.3175.

6. F. D. Owa, Mediterr. J. Soc. Sci., 4 (2013) 65.

https://doi: 10.5901/mjss.2013.v4n8p65

7. I. Reinholds, I. Pugajeva, I. Perkons, E. Lundanes, J. Rusko, G. Kizane, V. Nikolajeva, O. Mutere, Z. Petrina, L. Baumane and V. Bartkevics. Int. J. Environ. Sci. Tech., 14 (2017) 1969. https://doi.org/10.1007/s13762-0171290-6

8. S. Castiglioni, R. Bagnati, R. Fanelli, F. Pomati, D. Calamari and E.
Zuccato, Environ. Sci. Tech., 40 (2006) 357.

https://doi.org/10.1021/es050991m

9. A. Kaleniecka and P. K. Zarzycki, Arch. Physio. G. Res., 19 (2015) 39.

http://apgr.wssp.edu.pl/wpcontent/uploads/2015/10/artykul-4.pdf.

10. C. I. Kosma, D. A. Lambropoulou and T. A. Albanis, Sci. Total Environ., 466 (2014) 421.

https://doi.org/10.1016/j.scitotenv.2013. 07.044

11. T. Kosjek, E. Heath and A. Krbavcic, Environ. Int., 31 (2005) 679. https://doi.org/10.1016/j.envint.2004.12. $\underline{001}$

12. O. Olarinmoye, A. Bakare, O. Ugwumbaand and A. Hein, J. Environ. Chem. Ecotoxicol., 8 (2016) 14. http:// doi:10.5897/JECE2015.0364

13. H. Li, Z. Dong, Q. Weng, C. C. Chang and B. Liu, W. Environ. Res., 87 (2015) 1849.

https://doi.org/10.2175/106143015X143 38845156425

14. M. Scheurell, S. Franke, R. M. Shah and H. Huhnerfuss, Chemos., 77 (2009) 870. https://doi.org/10.1016/j.chemosphere.20 09.07 .066

15. A. Marchlewicz, D. Domaradzka, U. Guzik and D. Wojcieszyńska, Water, Air Soil Pollut., 227 (2016) 197. https://doi.org/10.1007/s11270-0162893-0

16. S. Straube, M. R. Tramèr, R. A. Moore, S. Derry and H. J. McQuay. BMC Gastroenterol., 9 (2009) 41. https://doi.org/10.1186/1471-230X-9-41

17. D. Stülten, S. Zühlke, M. Lamshöft and M. Spiteller, Sci. Total Environ., 405 (2008) 310.

https://doi.org/10.1016/j.scitotenv.2008. 05.036

18. G. L. Brun, M. Bernier, R. Losier, K. Doe, P. Jackman and H. B. Lee, Environ. Toxicol. Chem., 25 (2006) 2163. 
https://doi.org/10.1897/05-426R.1

19. M. D. Celiz, J. Tso and D. S. Aga, Environ. Toxicol Chem., 28 (2009) 2473. https://doi.org/10.1897/09-173.1

20. L. H. Santos, A. N. Araújo, A. Fachini, A. Pena, C. Delerue-Matos and M.C.B.S.M. Montenegro, J. Hazard. Mater, 175 (2010) 45.

https://doi.org/10.1016/j.jhazmat.2009.1 $\underline{0.100}$

21. US EPA. Method 1694, Water Sci. Tech. Eng. Anal. Divis., (2007). HPLC/MS/MS, EPA-821-R-08-002

22. A. Togola and H. Budzinski, Anal. Bioanal. Chem., 388 (2007) 627. https://doi.org/10.1007/s00216-0071251-X

23. G. Shanmugam, S. Sampath, K. K. Selvaraj, D. J. Larsson and B. R. Ramaswamy, Environ. $\quad$ Sci. $\quad$ Pollut. Res., 21 (2014) 921. https://doi.org/10.1007/s11356-013$\underline{1957-6}$

24. I. A. Kandhar and A. K. Ansari, Mehran University Res. J. Eng. Technol., 21 (2002) 141.

https://inis.iaea.org/search/search.aspx?o rig_q=journal:\%22ISSN\%200254$7821 \% 22$

25. B. P. Gumbi, B. Moodley, G. Birungi and P. G. Ndungu. Chemos., 168 (2017) 1042.

https://doi.org/10.1016/j.chemosphere.20 16.10.105

26. L. M. Madikizela and L. Chimuka, Water SA, 43 (2013) 264. https://doi: $10.4314 /$ wsa.v43i2.10

27. T. Deblonde, C. Cossu-Leguille and P. Hartemann, Int. J. Hyg. Environ. Health, 214 (2011) 442.

https://doi.org/10.1016/j.ijheh.2011.08.0 $\underline{02}$
28. K. Aguilar-Arteaga, J. A. Rodriguez, J. M. Miranda, J. Medina and E. Barrado, Talanta, 80 (2010) 1152. https://doi.org/10.1016/j.talanta.2009.08. $\underline{042}$

29. C. Lacey, S. Basha, A. Morrissey and J. M. Tobin, Environ. Monit. Asses., 184 (2012) 1049.

https://doi.org/10.1007/s10661-011$\underline{2020-\mathrm{Z}}$

30. A. Y. Lin, T. H. Yu and C. F Lin, Chemos., 74 (2008) 131. https://doi.org/10.1016/j.chemosphere.20 $\underline{08.08 .027}$

31. A. E. B. Kermia, D. Fouial-Djebbar and M. Trari. Compt. Rend. Chi., 19 (2016) 963.

https://doi.org/10.1016/j.crci.2016.05.00 5

32. M. Villanueva-Rodríguez, R. BelloMendoza, A. Hernández-Ramírez and E. J. Ruiz-Ruiz, Environ. Tech., 40 (2019) 2436.

https://doi.org/10.1080/09593330.2018.1 $\underline{442880}$

33. World Health Organization. (2012). Pharmaceuticals in drinking-water. ISBN 9789241502085

34. B. W. Schwab, E. P. Hayes, J. M. Fiori, F. J. Mastrocco, N. M. Roden, D. Cragin, R. D. Meyerhoff, J. D. Vincent and P. D. Anderson, Regulat. Toxicol. Pharm., 42 (2005) 296.

https://doi.org/10.1016/j.yrtph.2005.05.0 $\underline{05}$

35. N. Mater, F. Geret, L. Castillo, V. Faucet-Marquis, C. Albasi and A. PfohlLeszkowicz, Environ. Int., 63 (2014) 191.

https://doi.org/10.1016/j.envint.2013.11. $\underline{011}$ 